\title{
The achievement of middle school students' mathematical problem solving abilities through project-based learning models
}

\author{
Dahlia Fisher1, Yaya Sukjaya Kusumah', Jarnawi Afghani Dahlan ${ }^{1}$ \\ ${ }^{1}$ Universitas Pendidikan Indonesia \\ 四 dahliafisher1981@gmail.com*
}

\section{Article Information}

Submitted May 10, 2021

Revised May 12, 2021

Accepted May 13, 2021

\section{Keywords}

Mathematical Problem-Solving

Ability;

Project Based Learning.

\section{Abstract}

This research aims to determine the use of project-based learning $(\mathrm{PjBL})$ in the achievement of students' mathematical problem-solving abilities. The variables in this research were $\mathrm{PjBL}$ and mathematical problemsolving abilities. The instrument in this research was a description test of mathematical problem-solving abilities, which was analyzed by testing the hypothesis using the Mann Whitney $U$ test. The results showed that the average value of students learning using PjBL was higher than students learning using conventional models. The results of the Mann Whitney test show that learning using $\mathrm{PjBL}$ is effective in improving students' mathematical problem-solving abilities.

\section{INTRODUCTION}

Basic skills in reading, writing and arithmetic are no longer sufficient to compete in a challenging $21^{\text {st }}$ century. The education that is carried out must be able to prepare students to compete in the global community (Nahdi, 2019). This statement is reinforced by (Karmana, 2010) who argues that the demands of 21 st century education and the goals of national education, especially in mathematics learning, emphasize the development of students' potential to become independent learners, so that students have critical, creative, innovative thinking skills, and able to solve life problems. Mathematics learning means learning to solve problems, both problems related to everyday problems and solving math problems itself. In line with that, the goal of mathematics in the school is that students can solve math problems that are included in problem solving (Direktorat Pembinaan Sekolah Menengah Pertama, 2009). Talking about the problem-solving abilities proposed by some researchers, it can be said that problem solving is part of mathematics learning (NCTM, 2000). Mathematical problem solving is cognitively complex. Some mathematical literature describe problem solving as a number of activities that create patterns, interpret numbers, develop geometric constructions and prove theorems (Wilson et al., 1993). Amalia et al., (2017) stated that problem solving is the center of mathematics learning in the school. (Kilpatrick et al., 2002) said that in almost every domain of mathematics it shows that problem solving provides an important context that students can learn about numbers and other math topics. Problemsolving abilities are important for every student because problem solving abilities are at the core of the mathematics learning process and basic skills in mathematics learning (Hendriana et al., 2018). Correspondingly, solving mathematical problems is undoubtedly the heart of mathematical activities and mathematics learning. This is evident in both teacher-centered and student-centered learning models (Napitupulu \& Mansyur, 2011). 
Through the constructivism approach, teachers cannot simply provide knowledge to students, so that the knowledge given is meaningful, students themselves must process the information they receive, restructure it and integrate it with the knowledge they have. (Candiasa \& Sukajaya, 2018). The teacher has the role of providing support and giving students the opportunity to apply their own ideas and strategies in learning. Not only that, (Wulandari et al., 2016) suggest that students have difficulty solving problems in mathematics, but problem solving in mathematics learning is an important factor because it is a basic skill that students must master. One of the difficulty factors is inseparable from the learning model that is not in accordance with mathematics learning. Through the constructivism approach, students actively build their own knowledge. Based on that, many researchers have applied various learning models to support efforts in order to improve students' problem-solving abilities.

The importance of mathematical problem-solving abilities for students is a reason that efforts are needed to improve and enhance mathematics learning, through an innovation in learning using an appropriate learning model or approach. The reason is so that students can practice using their abilities and practice problem solving to explore abilities and develop ideas or strategies in problem solving. One model that can be applied based on this is the project-based learning model (PjBL).

(Rahmazatullaili et al., 2017) argued that the students' mathematical problem-solving abilities after the application of project-based learning were better than before the application. Cocco in (Kokotsaki et al., 2016) describe that project-based learning is a form of studentcentered teaching that is based on three constructivist principles, namely, context-dependent learning, students are actively involved in the learning process and they achieve their goals through social interaction by sharing knowledge and understanding. It is considered to be a type of inquiry-based learning where the context of learning is provided through questions and authentic problems in real-world practice (Al-Balushi \& Al-Aamri, 2014) that lead to meaningful learning experiences (Wurdinger et al., 2007). Project-based learning, provides opportunities for students to construct their knowledge, by solving real problems through questions, investigations, data collection, analyzing and interpreting information and data as well as drawing conclusions and reporting findings (Blumenfeld et al., 2000).

(Bell, 2010) said that project-based learning is a key strategy for creating independent thinkers. Students can solve real-world problems by designing their own questions, planning their learning, organizing their research, and applying many things to learning. PjBL is an approach for students to build knowledge through teamwork and problem solving by scientific methods (Krajcik et al., 2018). Over the years, project-based learning has been applied to a learning practice. In practice, students usually concentrate on group learning and present various results (Tseng et al., 2013). In their researches, (ChanLin, 2008) and (Karaman \& Celik, 2008) show that students who learn using project-based learning do better at developing skills, general abilities and compilation of knowledge than those who do not use project-based learning. In addition, it is said that project-based learning helps improve students' positive learning attitudes towards technology (Mioduser \& Betzer, 2008) and science (Martin-Dunlop \& Fraser, 2008). Based on the description above, the purpose of this research is to see the average difference in the mathematical problem-solving abilities based on project-based learning models and conventional learning (PKv). 
(Purnomo \& Mawarsari, 2014) revealed the results of their research that the IDEAL learning model of project-based learning-based problem solving (PBL) can improve the problem-solving abilities of prospective teacher students. Followed by the discovery of the research of (Nurfitriyanti, 2016) with the subject of high school students, found that the use of project-based learning models had an influence on students' mathematical problem-solving abilities. The same thing was done by (Muslim, 2017) that there was a positive influence on the use of the Project Based Learning model on the mathematical problem-solving ability of high school students. It is different with (Prabawa, 2017) who uses project-based learning with ethno-mathematical nuances in junior high school students, stating that the $\mathrm{PjBL}$ learning model with ethno-mathematical nuances is effective and can be an alternative choice for teachers to develop students' level of problem solving abilities. In contrast to the researches mentioned above, in practice the researcher uses a project-based learning model (PjBL) in the achievement of mathematical problem-solving abilities of junior high school students.

\section{METHODS}

This research aims to examine the effect of project-based learning model treatment on a class. Thus, this research is an experimental research. This research was conducted in one of the junior high schools in Bandung city. The population is all $8^{\text {th }}$ grade students who take part in semester 2 of 2018 which consists of eight classes with a total of 240 students. The sample in this research were 33 students who were taught with PBL and 32 students who were given conventional learning. The variables in this research are the PjBL model and mathematical problem-solving abilities. The research instrument consisted of mathematical problem-solving ability tests. The instrument test of the mathematical problem-solving ability test was carried out in $9^{\text {th }}$ grade with 34 respondent students. Based on the results of the trial, 5 descriptive questions were obtained which were used as a tool to determine the data on students' mathematical problem-solving abilities. The instrument was analyzed by testing the Mann Whitney U Test hypothesis. The selection of the Mann Whitney U test was due to the fact that the sample did not meet the main requirements for data normality. The research procedure used in this research can be seen in the following flowchart:

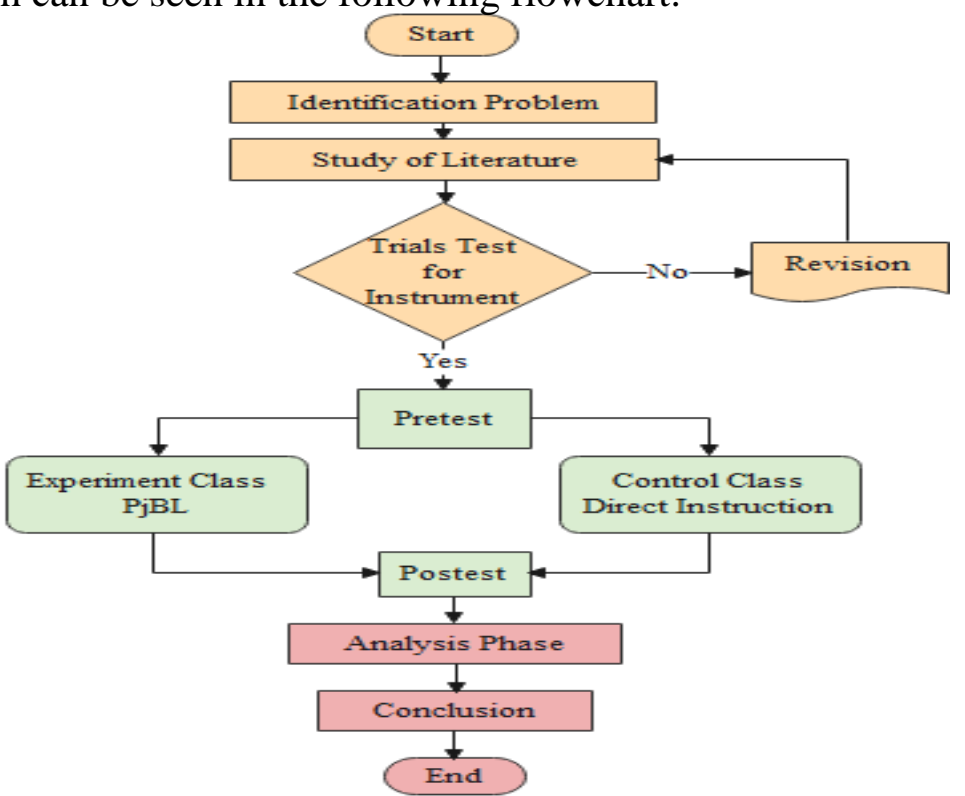

Figure 1. Research Flowchart 
The criteria for the achievement of students' mathematical problem-solving abilities were adapted from (Noer, 2010), as seen in Table 1.

Table 1. The Achievement of Mathematical Problem-Solving Ability Criteria

\begin{tabular}{cl} 
Test Score $(\mathrm{X})$ & Category \\
\hline$X \geq 70 \%$ & High \\
$60 \% \leq X<70 \%$ & Moderate \\
$X<60 \%$ & Low \\
\hline
\end{tabular}

\section{RESULTS AND DISCUSSION}

Analysis of students' mathematical problem-solving abilities begins with descriptive statistics which include mean, $(\bar{x})$ and standard deviation $(s)$, pretest score, post-test students' mathematical problem-solving abilities. The data provided are as follows.

Table 2. Descriptive Statistics Data of Mathematical Problem-Solving Ability

\begin{tabular}{cllllll}
\hline Stat. & $\begin{array}{l}\text { PjBL } \\
\text { Pretest }\end{array}$ & Post-test & $n$ & $\begin{array}{l}\text { PKv } \\
\text { Pretest }\end{array}$ & Post-test & $n$ \\
\hline $\bar{x}$ & 58,68 & 84,02 & & 56,06 & 71,88 & \\
$S$ & 16,02 & 9,95 & 32 & 19,31 & 16,19 & 33 \\
$S E$ & 2,83 & 1,75 & & 3,36 & 2,81 &
\end{tabular}

Based on the table above, it can be seen that the average value of the test in the experimental class is higher than the average value of the test in the control class both at the pretest and the post-test. The standard deviation of the experimental class is lower than the standard deviation in the control class. It means that, the distribution of student learning outcomes in the experimental class is less than the control class. This identifies that if it is look at the diversity of data for each class, the ability to solve math problems in the experimental class is almost the same. The test scores of students' mathematical problem-solving abilities in the experimental class and control class were grouped based on the indicator of problem-solving abilities.

The percentage of the achievement of students' mathematical problem-solving abilities based on learning groups $(\mathrm{PjBL}$ and $\mathrm{PKv})$ can be seen more clearly in the following bar chart.

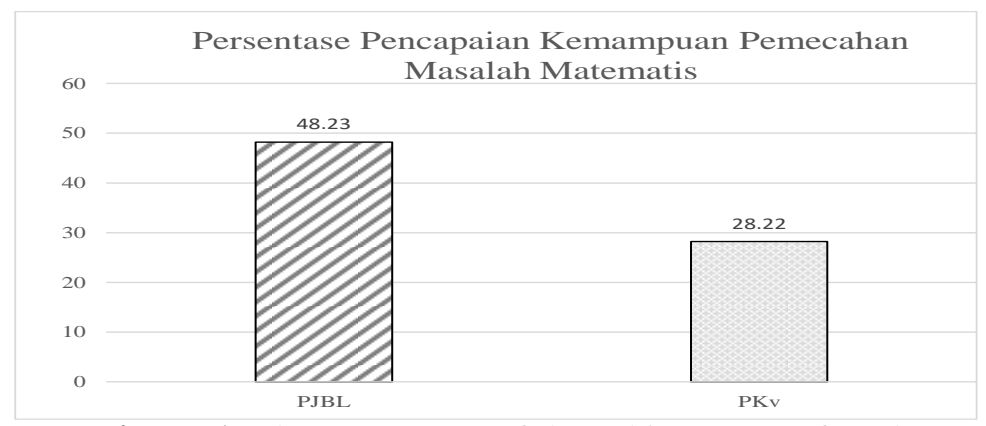

Figure 1. The percentage of the achievement of students' mathematical problem-solving abilities

The graph above shows that the percentage of achievement of mathematical problem-solving abilities of students who get PjBL learning is greater than students who get conventional learning $(\mathrm{PKv})$, and the percentage of achievement of mathematical problem-solving abilities for the $\mathrm{PjBl}$ and $\mathrm{PKv}$ classes is low.

Furthermore, to determine whether or not there is a difference in the average of the two pretest groups, the Mann-Whitney U non-parametric statistical test was used, because the 
pretest data were not normally distributed. The results of the pretest data on average difference test are presented in Table 2

Table 3. The difference test of the mean pretest data on mathematical problem-solving abilities

\begin{tabular}{lllll}
\hline Models & Mean Rank & Mann-Whitney U(Z) & Sig. (2-tailed) & $\boldsymbol{H}_{\mathbf{0}}$ \\
\hline PjBL & 34,80 & $-0,760$ & 0,447 & Accepted \\
\hline PKv & 31,26 & & &
\end{tabular}

The results of the analysis in the table above, it is known that the probability value (sig.) In each learning category is greater than the 0.05 significance stage so that the null hypothesis is accepted. This means that there is no difference in mathematical problem-solving abilities between the experimental group ( $\mathrm{PjBL}$ ) and the average pretest score of the control group $(\mathrm{PKv})$. These results provide the conclusion that before being given different treatment between the experimenters who received PjBL learning and the control class who received PKv learning.

The data on the achievement of mathematical problem-solving abilities were obtained from the posttest scores of mathematical problem-solving abilities obtained by students in Table 1. It can be seen that the average data on the achievement of mathematical problemsolving abilities of students who received PjBL learning was greater than students who received PKv learning.

Based on the normality and homogeneity tests that were carried out using SPSS 25, it is known that the data are not normally distributed, so to determine the average similarity, nonparametric tests are used using the Mann Whitney U test. Using the Mann Whitney U test, the following results are obtained:

Table 4. The Difference Test of Mean Posttest Data on Mathematical Problem-Solving Abilities

\begin{tabular}{lllll} 
Models & Mean Rank & Mann-Whitney U(Z) & Sig. (2-tailed) & $\boldsymbol{H}_{\mathbf{0}}$ \\
\hline PjBl & 40,95 & $-3,378$ & 0,001 & Rejected \\
\hline Conventional & 25,29 & &
\end{tabular}

The results of the Mann-Whitney test produce a probability value (sig.) that is smaller than the specified significance level of 0.05 , so that the null hypothesis is rejected. This means, there is a significant difference between the average data on the achievement of students' mathematical problem-solving abilities who get $\mathrm{PjBL}$ learning and students who get $\mathrm{PKv}$ learning. Based on the results of the analysis of the difference test on the average achievement and the average score of the achievement of mathematical problem-solving abilities of students who get PjBL learning and students who get PKv learning, it can be concluded that overall, the achievement of students' mathematical problem-solving abilities who get PjBL learning is better than students who get conventional learning.

The implementation of project-based learning was begun by providing a project work plan sheet to participants with the aim of knowing the extent to which students understand the material provided with the contextual problem to be worked on. The project worksheet contains questions in the form of a flow map or a project implementation plan containing basic questions that lead to the project planning design, such as: (1) what will be done ?; (2) how is the story to be completed ?; (3) what calculations will be carried out ?; (4) What information is required ?; (5) how to get the required data and what equipment is needed ?; (6) how to use information or calculations to answer questions ?; (7) how to organize and display it ?; (8) how to present the final results of this project? After students have successfully filled 
in the project planning sheet, proceed with compiling a schedule of activities in groups according to the predetermined plan. The role of the teacher in depth in this model is when monitoring students, namely by facilitating students in each process carried out to test the results and evaluate the experiences.

Project-based learning compared to conventional learning is more focused on the process and the product value obtained is not only test scores but also the real achievements. This is in line with the research conducted by (Putra, 2017) which states that the application of a contextual learning approach can improve students' problem-solving abilities in mathematics. (Fisher et al., 2020) Budi and Lala also revealed that the core of project-based learning, namely: (1) focus on students' ideas; (2) relevant to student interests; (3) encouraging students to be independent; (4) solving problems with an effective and attractive strategy; (5) helps develop problem solving skills. Learning activities using the PjBL model keep students busy with existing projects so that they can enjoy every learning activity. Although not everyone likes it, the impact of the PjBL learning model can help students to solve their doubts in learning mathematics and can foster enthusiasm for learning and increase academic involvement (Craft \& Capraro, 2017; Pratiwi et al., 2020).

\section{CONCLUSIONS}

Based on the research results, the mathematical problem-solving abilities of students who learn using the PjBL model are better than students who learn using conventional models, even though the percentage of achievement is low. It can be seen from the average score of students' learning tests taught using the PjBL model which is higher than the average scores of students who learn using conventional learning models. The significance value for mathematics learning with the PBL model is less than 0.05. Therefore, $\mathrm{H}_{\mathrm{o}}$ is rejected and $\mathrm{H}_{1}$ is accepted. This means that PjBL can significantly improve mathematical problem-solving abilities. So, it can be concluded that the use of PjBL in the teaching and learning process is effective in improving mathematical problem-solving abilities for students. This is because when students learn with $\mathrm{PjBL}$, students can discover the importance of mathematics in everyday life.

Based on the conclusions above, as a follow-up to this research the researchers would like to convey that through project-based learning, teachers are expected to focus on student learning on mathematical problem-solving abilities and to other researchers who wish to conduct this research, that project-based learning models can be used with a learning approach or it can even be used to improve higher-order mathematical thinking skills such as critical thinking skills, communication, and creative mathematics.

\section{AUTHOR CONTRIBUTIONS STATEMENT}

DF worked as the main drafter in this research. data collection and instrument design assisted by YSK and JAD.

\section{REFERENCES}


Al-Balushi, S. M. \& Al-Aamri, S. S. (2014). The effect of environmental science projects on students environmental knowledge and science attitudes. International Research in Geographical and Environmental Education, 23(3), 213-227.

Amalia, E., Surya, E., \& Syahputra, E. (2017). The effectiveness of using problem based learning (PBL) in mathematics problem solving ability for junior high school students. International Journal of Advance Research and Innovative Ideas in Education, 3(2), 3402-3406.

Bell, S. (2010). Project-based learning for the 21st century: Skills for the future. The Clearing House: A Journal of Educational Strategies, Issues and Ideas, 83(2), 39-43.

Blumenfeld, P., Fishman, B. J., Krajick, J., Mark, R. W., \& Soloway, E. (2000). Creating usable innovations in systemic reform: Scaling up technology-embedded project-based science in urban schools. Educational Psychologist, 35(3), 149-164.

Candiasa, I. M. \& Sukajaya, I. N. (2018). Pengaruh model pembelajaran berbasis proyek berbantuan geogebra terhadap kemampuan pemecahan masalah matematika pada materi bangun ruang sisi datar kelas VIII SMP PGRI 2 Denpasar. Jurnal Pendidikan Dan Pembelajaran Matematika Indonesia, 7(2), 131-141.

ChanLin, L. J. (2008). Technology integration applied to project-based learning in science. Innovations in Education and Teaching International, 45(1), 55-65.

Craft, A. M. \& Capraro, R. M. (2017). Science, technology, engineering, and mathematics project-based learning: Merging rigor and relevance to increase student engagement. Electronic International Journal of Education, Arts, and Science, 6, 140-158.

Direktorat Pembinaan Sekolah Menengah Pertama. (2009). Buku saku kurikulum tingkat satuan pendidikan (KTSP) sekolah menengah pertama. Departemen Pendidikan Nasional. 30.

Fisher, D., Kusumah, Y. S., \& Dahlan, J. A. (2020). Project-based learning in mathematics: A literatur review. Journal of Physics: Conference Series, 1657(1).

Hendriana, H., Purwasih, R., Triawan, E., Prasetio, Y., \& Satria, T. (2018). Analysis of student problem solving skill and activity concentration on a senior high school. AlJabar: Jurnal Pendidikan Matematika, 9(1), 1-8.

Karaman, S. \& Celik, S. (2008). An exploratory study on the perspectives of prospective computer teachers following project-based learning. International Journal of Technology and Design Education, 18(2), 203-215.

Karmana, I. W. (2010). Pengaruh strategi PBL dan integrasinya dengan STAD terhadap kemampuan pemecahan masalah, kemampuan berpikir kritis, kesadaran metakognitif, dan hasil belajar kognitif biologi pada siswa kelas X SMA Negeri 4 Mataram [Universitas Mataram].

Kilpatrick, J., Swafford, J., \& Findell, B. (2002). Adding it up: Helping children learn mathematics. The National Academies Press. The book is available free on the Web. Accessed, 2(4), 04.

Kokotsaki, D., Menzies, V., \& Wiggins, A. (2016). Project-based learning: A review of the literature. Improving Schools, 19(3), 267-277.

Krajcik, J. S., \& Czerniak, C. M. (2018). Teaching science in elementary and middle school: A project-based learning approach. Routledge.

Martin-Dunlop, C., \& Fraser, B. J. (2008). Learning environment and attitudes associated with an innovative science course designed for prospective elementary teachers. International Journal of Science and Mathematics Education, 6(1), 163-190. 
Mioduser, D., \& Betzer, N. (2008). The contribution of project-based-learning to highachievers' acquisition of technological knowledge and skills. International Journal of Technology and Design Education, 18(1), 59-77.

Muslim, S. R. (2017). Pengaruh penggunaan model project based learning terhadap kemampuan pemecahan masalah matematis peserta didik. Supremum Journal of Mathematics Education, 1(2), 88-95.

Napitupulu, E., \& Mansyur, A. (2011). Kemampuan pemecahan masalah matematis siswa (studi kasus di SMA negeri Parongpong kabupaten Bandung Barat). GENERASI KAMPUS, 4(1).

NCTM. (2000). Principles council of teachers mathematics. Reston. VA.

Noer, S. H. (2010). Peningkatan kemampuan berpikir kritis, kreatif, dan reflektif (K2R) matematis siswa SMP melalui pembelajaran berbasis masalah. Disertasi UPI: Tidak diterbitkan.

Nurfitriyanti, M. (2016). Model pembelajaran project based learning terhadap kemampuan pemecahan masalah matematika. Formatif, 6(2), 1149-1160.

Prabawa, E. A. (2017). Analisis kemampuan pemecahan masalah ditinjau dari gaya kognitif siswa pada model project based learning bernuansa etnomatematika. Unnes Journal of Mathematics Education Research, 6(1), 120-129.

Pratiwi, G., Sova, F., Putra, F. G., Yunian Putra, R. W., Kusuma, A. P., \& Rahmawati, N. K. (2020). The influence of project-based learning (PjBL) and learning style om mathematics communication skills of junior high school students. Journal of Physics: Conference Series, 1467(1).

Purnomo, E. A., \& Mawarsari, V. D. (2014). Peningkatan kemampuan pemecahan masalah melalui model pembelajaran ideal problem solving berbasis project based learning. Jkpm, 1(1), 24-31.

Putra, F. G. (2017). Eksperimentasi pendekatan kontekstual berbantuan hands on activity (HoA) terhadap kemampuan pemecahan masalah matematik. Al-Jabar: Jurnal Pendidikan Matematika, 8(1), 73-80.

Rahmazatullaili, Zubainur, C. M., \& Munzir, S. (2017). Kemampuan berpikir kreatif dan pemecahan masalah matematis siswa SMA. Jurnal Tadris Matematika, 10(2), 166-183.

Nahdi, S. D. (2019). Keterampilan matematika di abad 21. Jurnal Cakrawala Pendas, 5(2), $133-140$.

Tseng, K. H., Chang, C. C., Lou, S. J., \& Chen, W. P. (2013). Attitudes towards science, technology, engineering and mathematics (STEM) in a project-based learning (PjBL) environment. International Journal of Technology and Design Education, 23(1), 87102.

Wilson, J. W., Fernandez, M. L., \& Hadaway, N. (1993). Mathematical problem solving. Research ideas for the classroom: High school mathematics, 57, 78.

Wulandari, P., Mujib, M., \& Putra, F. G. (2016). Pengaruh model pembelajaran investigasi kelompok berbantuan perangkat lunak maple terhadap kemampuan pemecahan masalah matematis. Al-Jabar : Jurnal Pendidikan Matematika, 7(1), 101-106.

Wurdinger, S., Haar, J., Hugg, R., \& Bezon, J. (2007). A qualitative study using project-based learning in a mainstream middle school. Improving Schools, 10(2), 150-161. 